\title{
THE EFFECT OF INTRARUMINAL INFUSION OF IODINATED CASEIN ON THE POTENTIAL DEGRADABILITY OF PANICUM MAXIMUM IN WEST AFRICAN DWARF X UDA SHEEP
}

\author{
AKA,L. O. ' ; OBIDIKE, R.I ${ }^{1}$ AND UDEGBUNAM, S.I ${ }^{2}$ \\ ${ }^{1}$ Department of Veterinary Physiology/Pharmacology \\ University of Nigeria, Nsukka, Nigeria. \\ ${ }^{2}$ Department of Veterinary surgery, University of \\ Nigeria, ,Nsukka, Nigeria \\ "Correspondence: Lawman3@yahoo.com
}

$+2348035413914$

\section{SUMMARY}

The quantitative (percentage) rumen degradability of Panicum maximum at $48 \mathrm{hrs}$ post rumen incubation was studied in West African (Northern) long-legged sheep using the nylon bag technique, in a 4x4 Latin square experimental design of; four sheep, four time intervals, four experimental rounding of same sample and four levels of iodinated casein. The animals had an average body weight of $9.61 .46 \mathrm{~kg}$. They were fitted with rumen fistula through which Panicum maximum were incubated. Various dose ranges of $1.5 \mathrm{~g}, 2.5 \mathrm{~g}, 3.5 \mathrm{~g}$, and $4.5 \mathrm{~g}$ of iodinated casein were infused into the rumen 8 hrs prior to the incubation. Potential rumen degradability of Panicum maximum was determined at time intervals of $4,8,12$ and $48 \mathrm{hrs}$ post incubation. The results of the experiment showed that infusing a maximum dose of $3.5 \mathrm{~g}$ of iodinated casein produced marked improvement in the rumen degradability of dry matter, organic matter and crude protein fractions of Panicum maximum and beyond this limit the effect decreased. The increase in rumen potential degradability of all the fractions of Panicum maximum was significantly different $(\mathrm{p}<0.05)$ between the treatment groups of $2.5 \mathrm{~g}$ and $3.5 \mathrm{~g}$ of iodinated casein and the control as well as among the extremes of the treatment groups. This increase was however found to be dose (iodinated casein) dependent The result of this experiment will hopefully expand the possibilities of exploiting the nutritional benefits of some ruminant feeds particularly the more fibrous, rumen undergradable, non-conventional feed resources through the inclusion of appropriate levels of iodinated casein in ration containing them. In so doing, the scope of feed resources for ruminants may be expanded.

KEY WORDS: Rumen, degradability, iodinated casein, Panicum maximum, sheep. 


\section{INTRODUCTION}

Measuring feed fraction degradability within the rumen is usually a difficult task (Hungate, 1966). For this reason in vitro studies involving cultures of rumen microbes are usually preferred (Czerkawski, 1986). In such studies numerous factors are known to modulate the events studied (Kaitho etal., 1993).

Researchers in ruminant nutrition have attempted various ways of improving the utilization of both conventional and nonconventional feed resources by ruminant animals. The involvement of rumen microbes in the breakdown of feedstuffs opens many ideas towards this purpose. It sounds therefore biologically logical to state that improving the activity of the rumen microbes by whatever means, may enhance better bioavailability of contents of these substances upon which they act. Activity of rumen microbes have been modulated in various ways namely; grinding of feedstuffs improves degradability (Weston and Hogan, 1967); defaunation improves ruminal bacterial activity (Jacques et al., 1987); enzyme inclusion in feed improves digestibility (Cooper et al., 1995); temperature regulation modifies microbial synthesis (Kennedy and Milligan, 1978); season affects degradability (Arigbede $e t$ al., 2002). These methodologies/strategies are generally targeted towards developing a feeding programme that will enhance better degradability,

nutrient bioavailability and utilization. Newer methods such as rumen degradability characteristics of feeds, especially roughages, have been used to describe the nutritional value of feeds for ruminant animals (Bhagara and Orskov, 1987).

Under natural conditions, ruminants utilize forages as defined by the in vivo degradative capacities of the rumen microbes, (Czerkwaski, 1986), rumen rate of passage (Verbic et al., 1999) and other factors. However, according to Leng (1974), the natural dimitations in the digestive physiology of an animal can be readily improved by the use of both naturally occurring or synthetic agents. For instance the use of copper sulphate, at certain concentrations, to reduce protozoal population has been used to improve rumen degradability of forages (Melvin, 1993). Likewise intra-ruminal infusion of free amino acids have resulted in improved digestibility in steers (Spears and Harvey, 1984) but amino acid in peptides are incorporated by certain rumen microbes more efficiently than are free amino acids (Philipson, 1970). In order to further investigate this claim; that amino acids in peptides is beneficial in rumen microbial activity, this experiment was aimed at using iodinated casein as source of peptide amino acids and degradability characteristics of Paninicum maximum, to measure the activity of rumen microbes when iodinated casein is infused into the rumen.

\section{MATERIALSAND METHODS Animals}

Four West African Dwarf X Uda rams were bought from Ibagwa market in Nsukka local government area of Enugu state. They were quarantined for 21 days in a pen measuring $10 \mathrm{ft}$ $x 8 \mathrm{ft}$ in the farm unit of the Faculty of Veterinary Medicine, University of Nigeria, Nsukka. During this period they were examined for helminth ova using the flotation technique. They were dewormed using a combined prophylactic dose of ivermectin and piperazine at dose rates of $220 \mathrm{mg} / \mathrm{kg}$, subcutaneously and $44 \mathrm{mg} / \mathrm{kg}$, IM respectively (Merck Vet Manual, 1993). They were fed with fresh green forages and occasional grain supplementation. Feed and water were offered ad libitum. After the 21 days quarantine period they were weighed using a weighing beam. They were later prepared for surgical rumen fistulation as described by Dougherty (1955), Oladosu and Akpokodje (1992) and Aka and Kamalu (2004, 2005). Iodinated casein was prepared as described by Kneuzal et al (2005), using potassium iodide as the iodine source.

\section{Rumen incubation procedure}

The nylon bag technique as developed and described by Mehrez and Orskov (1.977) was adopted. Different measures of iodinated casein: $1.5 \mathrm{~g}, 2.5 \mathrm{~g}, 3.5 \mathrm{~g}$ and $4.5 \mathrm{~g}$ were introduced into the rumen of each sheep 12 hours before the incubation of the nylon 
bags that contained $1 \mathrm{~g}$ each of the Panicum maximum into the rumen. Prior to incubation the chemical composition of Panicum maximum was determined by a proximate analysis procedure. (Aka and Kamalu, 2004)

\section{Degradability studies}

The immediate water soluble fractions 'a' and the slowly rumen degradable fraction ' $b$ ' of dry matter, organic matter and crude protein for Panicum maximum were determined as described by Arigbede et al (2002), Aka and Kamalu (2004). The degradability characteristics of Panicum maximum at different doses of iodinated casein were monitored between $4-48 \mathrm{hrs}$ post rumen incubation.

\section{RESULTS}

Table I shows the normal chemical composition of Panicum maximum. The degradability of dry matter, organic matter and crude protein fraction of Panicum maximum in sheep on various intruraminal doses of iodinated casein at $48 \mathrm{hrs}$ is given in Table II. Table III: shows the potential degradability $\left(' a '+{ }^{\prime} b^{\prime}\right)$ of all the feed fractions expressed in percentages.

\section{TABLE I: Chemical composition of Panicum maximum (\% of dry matter)}

Feed sample Feed fractions

\begin{tabular}{lllllll} 
& $\begin{array}{l}\mathrm{CP} \\
(\%)\end{array}$ & $\mathrm{CF}(\%)$ & $\begin{array}{l}\mathrm{OM}, \\
(\%)\end{array}$ & $\begin{array}{l}\mathrm{ASH}, \\
(\%)\end{array}$ & $\begin{array}{c}\mathrm{EE}, \\
(\%)\end{array}$ & $\begin{array}{c}\text { NFE } \\
(\%)\end{array}$ \\
\hline $\begin{array}{l}\text { Panicum } \\
\text { maximum }\end{array}$ & 13.48 & 6.5 & 80 & 10 & 1.3 & 41.64 \\
\hline
\end{tabular}


TABLE II: Dry matter, organic matter and crude protein degradability of Panicum maximum in sheep with intraruminal iodinated casein at $48 \mathrm{hrs}$ post incubation

\section{Iodinated}

Casein

levels

(gms)

\section{Feed fraction}

\begin{tabular}{|c|c|c|c|c|c|c|}
\hline & $' a^{\prime}$ & 'b' & & 'b' & 'a' & 'b' \\
\hline 1.5 & 6.01 .01 & 462.73 & 1.40 .54 & 522.06 & 1.360 .76 & 8.283 \\
\hline $2 . \overline{5}$ & 5.20 .88 & $501.82^{a}$ & 1.30 .37 & $562.42^{a}$ & 1.280 .83 & $11.391 .33^{\mathrm{a}}$ \\
\hline $3 . \overline{5}$ & 6.40 .94 & $631.64^{\mathrm{a}}$ & 1.091 .81 & $731.84^{\mathrm{a}}$ & 1.930 .64 & $12.092 .46^{a}$ \\
\hline 4.5 & 6.30 .92 & $462.0^{\mathrm{a}}$ & 0.980 .8 & $542.54^{\mathrm{a}}$ & 1.260 .84 & 10.361 .0 .4 \\
\hline Control & 8.001 .03 & 421.36 & 10.01 & 391.46 & 1.200 .46 & 6.81 .76 \\
\hline
\end{tabular}

a immediate soluble fraction.

b- slowly rumen degradable fraction.

Values with 'a' superscript are significantly $(\mathrm{P}<0.05)$ different from the control.

TABLE III: Potential degradability of Panicum maximum at $48 \mathrm{hrs}$ post incubation in sheep with intraruminal addition of iodinated casein.

Iodinated

Casein

Levels

(gms)
Potential degradability (\%) at

48 hrs post incubation

\begin{tabular}{llll}
1.5 & 520.64 & 53.400 .54 & 68.640 .23 \\
\hline 2.5 & 55.20 .48 & 57.300 .48 & 91.530 .64 \\
\hline 3.5 & 69.40 .72 & 74.090 .37 & 98.760 .46 \\
\hline 4.5 & 52.30 .38 & 54.98062 & 83.950 .46 \\
\hline
\end{tabular}




\section{AKA et al: Degradability of panicum maximum in sheep}

\section{DISCUSSION}

The result of the experiment showed a significant $(p<0.05)$ increase in the degradability of Panicum maximum with addition of graded levels of iodinated casein into the rumen. It was also observed that degradability improved with increasing levels of iodinated casein up till the $3.5 \mathrm{~g}$ mark. Levels above 3.5 (e.g, $4.5 \mathrm{~g}$ ) yielded a poor degradability when compared with the $1.5 \mathrm{~g}$, to $3.5 \mathrm{~g}$ levels of iodinated casein. As shown in Tables II and III, iodinated casein produce improved degradability of all the feed fractions (dry matter organic matter and crude protein). There were marked increases in the degradability of each of these fractions. As the levels of iodinated casein increased from $1.5 \mathrm{~g}$ to $3.5 \mathrm{~g}$ the potential degradability increased from, $52 \%$ to $69.4 \%$ for dry matter, and $53.4 \%$ to $74.09 \%$ for organic matter and $68.64 \%$ to $98.76 \%$ for crude protein. These represents an increment of $17.4 \%$ for dry matter, 20.69 for organic matter and $30.12 \%$ for crude protein, as iodinated casein in increased from $1.5 \mathrm{~g}$ to $3.5 \mathrm{~g}$. When compared with the control, at $48 \mathrm{hrs}$ after incubation, increasing iodinated casein up to $3.5 \mathrm{~g}$ produced an increment in degradability of $19.4 \%$ for dry matter, 34.09 for organic matter and $41 \%$ for crude protein.

Meanwhile, it was also observed that increasing the level of iodinated casein beyond $3.5 \mathrm{~g}$ (e.g. $4.5 \mathrm{~g}$ as in this experiment) produced a decreased degradability effect. For instance for organic matter at $4.5 \mathrm{~g}$ of iodinated casein, the potential degradability decreased to $45.98 \%$ from $74.09 \%$ at $3.5 \mathrm{~g}$ level. These trends of events simply suggest that iodinated casein, improves the degradability characteristics of feedstuffs within a given limit beyond which a decrease degradability results. Again the benefits of iodinated casein is expressed in it's ability to overcome the detrimental effects of rumen undergradable polysaccharides (e.g NSP) such as, their ability to increase digesta viscosity (Bhat and Hazelwood, 2001), their ability to interact with the microflora of the gut, (Bedford and Apaja Lahti, 2002), and their ability to alter the physiology and morphology of the digestive tract (Spiehs et al., 2002), by degrading them and making them unavailable within the rumen and post ruminal segment of the gut.
As an attempt to explain the probable mechanism, it is suggested that iodinated casein increases either the growth of the microbial population of the rumen after some hours upon introduction into the rumen or by initiating a process(es) that increase the production, of bacterial enzymes within the rumen. Numerous factors have been shown to be involved in the regulation of the growth-rate of various species of rumen microbes (Hobson, 1969). Diet and time after feeding are also such factors (Nissen, 1992). The amino acid content of food increases the growth rate of rumen bacterial which in turn increases rumen protozoa population few hours after feeding (Mohammed and Smith, 1977). This could have accounted for the improved degradability since the Panicum maximum was incubated $8 \mathrm{hrs}$ after introduction of iodinated casein. It is probable that iodinated casein served as a source of amino acids, which were further utilized for microbial growth.

The trend where further increase in iodinated casein beyond 3.5 grames, did not yield a corresponding increase in degradation of feed fractions is however puzzling. It could be as a result of reduced bacterial population due to massive proliferation of rumen protozoa. With increased bacterial multiplication. and growth, rumen protozoa find much bacteria to feed on, and in so doing reduce their population and activity. The ecology of the rumen microbes seems to be regulated by interdependence of the microbes themselves. Based on this finding therefore, the effect of iodinated casein on the physiology and microbiology of the rumen can be said to be dose dependent. Studies of nutritional factors important for the growth of rumen microbes tend to emphasize the interdependence of the microbes and their fit into ecological niches (Hungate, 1966).

\section{CONCLUSION}

In conclusion, this experiment has provided some clues to the importance of iodinated casein in ruminant nutrition particularly in the improvement of rumen degradability. This idea can be employed to enhance the utilization of non starch polysaccharides (NSP) to enhance 
energy availability from them. Just as enzymes are used to improve the digestibility of nutrients from non-conventional feed resources in poultry, iodinated casein may serve a similar purpose in ruminants. It is therefore possible to produce commercial iodinated casein and consequently use it for the improvement of degradability of pectins and hemicellulose to yield sufficient metabolizable energy within the rumen, which in turn produce desirable heath outcomes in ruminants. The challenge of enhancing the nutritive value of conventional and non conventional feed resources for ruminants may be addressed by the incorporation of iodinated casein into ruminant diets.

It is recommended that further investigations into the mechanism by which iodinated casein brings about improved rumen degradability of feeds be carried out. Nevertheless, the results of this experiment may serve as basis for exploiting the benefits of incorporating iodinated casein into ruminant diets.

\section{REFERENCES}

AKA, L.O and KAMALU, T. N

(2005): The use of Cobalt EthylenediamineTetraacetic Acid as a soluble marker in the determination of Rumen outflow rate in sheep. Nig. Vet. $J_{., .}$26(1): 18-24.

AKA, L.O and KAMALU, T.N.

(2004): Rumen Degradability Characteristics of Stylosanthes gracils, Panicum maximum Pennisetum purpureum_and Centrosema pubescens in Sheep. Nig. Vet.J.,. 25(4):14-20

ARIGBEDE, O. U, BAMIKOLE, $M$.

A, Olanite, J. A; Jolaosho, A. O and Onifade,O. S. (2002): Seasonal Degradability of Dry Matter, Organic Matter and Crude Protein in some multipurpose tree species by West African Dwarf Goats. Proc. $29^{\text {th }}$ Ann. Conf. Nig. Soc. For Anim. Prod., 191194.
BEDFORD, M.R and APAJA

LAHTI (2002): Microbial

Interactions In TheResponse To

Exogenous Enzymes Utilization

Enzyme On Farm Animal Nutrition. M.

R .Bedford and G.G Partridge, Eds.

CABI publishing London; 299-314

BHARGARA, P. K and ORSKOV,

E.R (1987): Manual for the Use of NylonBag Technique in the Evaluation of Feedstuffs: For Feedstuff Evaluation and Experimental Development Services (FEEDS). The Rowrtt Research Institute Bucksburn. Aberdeen. AB 2, 9SB.

BHAT, M.K and HAZELWOOD, G.P (2001): Enzymology And Other Characteristics of Celluloses and Xylanases. Enzymes on Farm Animal Nutrition, M.R. Bedford and G.G. Partridge, Eds. CABI publishing London; 11-60.

COOPER C, SCHAFER, D. and

GREGG, K. (1995): Use of engineered rumen bacteria to degrade fluoroacetate. Proceeding of the Recent Advances in Animal Nutrition in Australia 1995. J.B Rowe and J.U Nolan, Eds. University of New England, Armidal, NSW 2357, Australia; 104107

CZERKAWSKI, J. W.(1986): An

Introduction to Rumen Studies; Oxford Pergamoa Press; 8693.

DOUGHERTY, R.W (1955):

Permanent Stomach and Intestinal

Fistulas on Ruminants. Cornel Vet., 86: 234-236.

HOPSON, P.N (1969): Microbial Interactions in the Rumen In $19^{\text {th }}$ symposium of the society for general microbiology. Meadow and S.J. Pirt (eds) University press, Cambridge; 43. 
HUUGATE, R.E (1966): The Rumen and its Microbes. W. Holmes, Ed. New York Academic press; 216-219.

JACQUES, K.A; COCHRAN, R.C, CORAH, L.R and AVERY, T.B (1987):Influence of Lasalocid Level on Forage intake, digestibility, ruminal fermentation, Liquid flow and performance of beef cattle grazing winter forage. J. Anim. Sci., . 65: 777785 .

\section{KAITHO, R.J; TAMMINGA, S. and}

BRUCHEM, J. (1993): Rumen degradation and In vivo Digestibility of dried Calliandra calothrysus leaves. Anim. Feed Sci. and Technol., 43:1930.

KENNEDY,P. M and MILLIGAN, L.P (1978): Effects of cold exposure on digestion, microbial synthesis and nitrogen transformations in sheep. Por. J. Nutr, 39.105.

KNEUZAL, W.J; WIDEMAN, R.F; CHAPMAN, M; GOLDEN, C and HOOGE, D.M (2005): A practical method for induced moulting of caged layers that combine full access to feed and water, dietary thyroative protein, and short day length. World's Poultry Science Journal.,. 61: 603-604.

LENG, R.A (1974): Digestion in the

Rumen. In Chemistry and Biochemistry of Herbage, Vol.3 [R.W. Baily and G. W Butler, editor] New York. Academic Press.

MELVIN, J.S (ed) 1993: Duke's

Physiology of Domestic Animals. Cornell, university Press. U.S.A ; 387 426.

\section{MERCK VETERINARY MANUAL.} (1993), Seventeenth edition. $A$ Handbook of Diagnosis, Therapy, and Disease Prevention and Control for the Veterinarian. Railway, N. J. U.S.A.
MOHAMMED, D.E and SMITH, R.H (1977): Measurement of protein degradation in the Rumen. Prod. Nur. Soc., 36, $152 \mathrm{~A}$.

NISSEN (ed) 1992: Modern Methods In Protein Nutrition And Metabolism. London Academic press.

OLADOSU. L.A and AKPOKODJE, J.U (1992): Rumen Fistulation of West African Dwarf Ram for digestibility studies. Trop. Vet.,. 10.33-36.

PHILIPSON, A.T. (eds) 1970. Physiology of Digestion and Metabolism in the Ruminant. Proceeding of the $3^{\text {tit }}$ International Symposium. Cambridge Orial Press England., 292 301, 474476.

SPEARS, J.W and HARVEY, R.W (1984): Performance, Ruminal and Serum Characteristics of Steers Fed Lasalocid on Pasture. J. Anim. Sci., $58: 460$.

SPIEHS, M.J, WLUTNEY, M.H, and SHURSON, G.C (2002): Nutrient database for distillers dried grains with soluble produced from new ethanol plants on Minnesota and south Dakota. J.Y Animal Science., 80:2639-2645.

VERBIC, T., ORSKOV, E.R; ZGAJNAR; CHEM, X.B and ZNIDARSIPONGRAC, V.; (1999): The effect of method of forage preservation on the protein degradability and microbial protein synthesis in the rumen. Anim. Feed Sci. Technical., 82:195-200.

WESTON, R.H and HOGEN, J.P.

(1967). The Digestion of chopped and round roughages by sheep. Aust. J. Agric. Res.,. 18: 789-801. 